\title{
‘This man has come into my house': Hospitality in Genesis 19; 34; and Judges 19.
}

This article explores narratives wherein themes of hospitality, sexual violence against women, and migration coalesce. The presence of migration and the theme of 'guest' and 'host' make Genesis 19, and in the linked tradition in Judges 19, particularly apt for analysis which uses modern literature coupling hospitality and migration as a heuristic tool. Indeed, as well as being thematic hospitality may also function in the narratives as a metaphor for immigrants and host communities. In Genesis 34, the metaphor of hospitality and the consequences of hospitality broken are also important thematically as is the desire for revenge. The article argues that in all three cases, group boundaries reach a new level of significance in response to migration, but are violently concretized in light of sexual exploitation.

Keywords Hospitality, Dinah, Lot, Concubine, Migration, Home.

Hospitality is an extremely evocative topic which has political, cultural, and ethical overtones; a notion that induces unrelenting questions about how the stranger, traveller, or migrant is to be welcomed. It suggests a structure which dichotomizes social relations between self and Other, inside and outside, kin and non-kin, home and away, private and public, as well as guest and host, both on an individual, and at an international, level. ${ }^{1}$ The concept is enormously relevant for contemporary discussions concerning migration but is an

\footnotetext{
${ }^{1}$ J. G. Molz and S. Gibson, 'Introduction: Mobilizing and Mooring Hospitality,' in J. G. Molz and S. Gibson (eds.), Mobilizing Hospitality: The Ethics of Social Relations in a Mobile World (Aldershot, England: Ashgate), pp. 1-28 ( 3).
} 
equally important idea for examining narratives of migration within the Hebrew Bible. ${ }^{2}$ However, despite its enduring prevalence in language referring to migration, the concept is particularly problematic and can exacerbate existing vulnerabilities faced by migrants. For example, Rosello suggests that discourses of hospitality blur distinctions between the language of "rights" and "generosity" and result in perceptions of immigrants as guests. This language obstructs them from feeling at home in the nation. Simultaneously, the opposition constructs the guest as powerless, drifting, and dispossessed and the host as powerful, permanent, and native. Such rhetoric emphasizes the Other-ness and outsider position of migrants and places them under a debt of hospitality to the host nation. ${ }^{3}$ Indeed, the notion of guest and host which is embedded within the language of hospitality camouflages a paradoxical type of inclusive exclusivity where the host nation are perceived as generous and tolerant yet where some groups of migrants and asylum seekers are, at the same time, seen as uninvited guests. Similarly, through the metaphors associated with hospitality the notion of

\footnotetext{
${ }^{2}$ The International Organization for Migration describes migration as

The movement of a person or a group of persons, either across an international border, or within a State. It is a population movement, encompassing any kind of movement of people, whatever its length, composition and causes; it includes migration of refugees, displaced persons, economic migrants, and persons moving for other purposes, including family reunification (https://www.iom.int/key-migrationterms).
}

This intentionally wide-ranging definition of migration does not account for the variety of ways the term "migrant" is used nor does it make a distinction between forced and voluntary migration (though the division between the two is often hazy; Ruth is not forced to leave Moab but she is also fleeing famine). Nevertheless, it usefully emphasises the dichotomy between movement (highlighting human mobility) and boarders (underlining nationalistically and politically constructed limits on mobility).

${ }^{3}$ M. Rosello, Postcolonial Hospitality: The Immigrant as Guest (Stanford, CA: Stanford University Press Books, 2001). 
home is presented as a 'domain of power where the host polices the conditions by which the front door remains open or closed. ${ }^{4}$

Cautious consideration of the implications of language is therefore required when the metaphor of hospitality and the theme of migration coalesce. Envisaging migrants as powerless, drifting, and dispossessed anonymises them and disregards their agency, talents, and potential. Indeed, this type of language results in the promulgation of myths about migrants. ${ }^{5}$ Furthermore, through depicting the migrant as "Other", notions of boundary maintenance usually associated with ethnic and national discourses may occur, giving rise to feelings of threat, primordial notions of ethnicity, unearned entitlement, and even racist attacks. ${ }^{6}$ Grove and Zvi illustrate this aptly through emphasizing how the construction of refugees as "other" results in exclusion and disempowerment as a consequence of perceived threat. ${ }^{7}$ Ill-considered metaphors of hospitality which seize notions of agency from migrants

\footnotetext{
${ }^{4}$ Molz and Gibson, 'Introduction: Mobilizing and Mooring Hospitality’, p. 12.

${ }^{5}$ For example five popular myths about refugees, which Oxford's Refugee Studies Centre recently highlighted, included perceptions that they are economically isolated and homogenous, a burden on host societies, technologically illiterate, and dependent on humanitarian assistance. A. Betts, L. Bloom, J. Kaplan, and N. Omata, Refugee Economies: Rethinking Popular Assumptions (Humanitarian Innovation Project: Oxford, 2014). ${ }^{6}$ Concerning ethnicity and nationalism refer to K. E. Southwood, Ethnicity and the Mixed Marriage Crisis in Ezra 9-10: An Anthropological Perspective. (Oxford Theological Monographs; Oxford: Oxford University Press, 2012), pp. 19-72.

${ }^{7}$ As Grove and Zvi state, the 'adoption of metaphors of threat, of natural disaster, of invasion, of war, and of contagion' such as 'metaphors of water, (drip, stream, flow)' can contribute to the construction of foreigners in an impersonal and destructive light'. Similarly, Grove and Zwi highlight the 'biblical references' which are used to describe refugees; populations 'pour across borders...they arrive in swarms, tides, and waves, threatening to swamp and overrun host communities' (N. J. Grove, and A. B. Zwi, 'Our Health and Theirs: Forced Migration, Othering, and Public Health,' Social Science \& Medicine, 62, (2000), pp. 1931-1942 (1934). Indeed, a term regularly used for refugees, “displaced persons” conjures up Douglas' definition of dirt as 'matter out of place'.
} 
can be particularly erosive to migrant women. This is especially the case when language concerning migration and women emphasises their vulnerabilities. As Fiddan-Qasmiyeh argues,

...accounts often reduced ... experiences to women's vulnerability to sexual violence, rather than exploring how and why women were victimized and persecuted, or recognizing that displaced women could simultaneously be victimized and yet remain active agents deserving of respect, and not simply pity. ${ }^{8}$

Thus, rather that homogenizing and anonymising "migrants" using the concept of hospitality, it is important to recognize different social groups and individuals among migrants, and not just in terms of gender vulnerabilities but also in terms of agency. Effectively, seemingly innocent metaphors such as guest and host must be deconstructed if the language and concepts associated with hospitality are to be used responsibly in discussions of migration.

\section{As Moltz and Gibson suggest,}

Thus, hospitality is not just about the gift of repose, but also about the gift of hope. Making the guest feel at home is not just about seeing to his or her physical comfort or embodied needs (though these are certainly important); it is also about instilling the guest with a feeling of hope and a sense of being 'propelled' forward ... hospitality provides not only a place to be safely still, but also the hope of moving: For what is security if it isn't the capacity to move confidently? .... A home has to be both closed enough to offer shelter and open enough to allow for this capacity to perceive what the world has to offer and to provide us with enough energy to go and seek it. ${ }^{9}$

Defining and constructing hospitality in this way is incredibly helpful since it is a positive, self-conscious description which takes into account awareness of difference, but also of

M. Douglas, Purity and Danger: An Analysis of Concepts of Pollution and Taboo (London: Routledge and Keegan Paul, 1966), p. 35.

${ }^{8}$ E. Fiddan-Qasmiyeh, 'Gender and Forced Migration,' in E. Fiddan-Qasmiyeh, G Loescher, K. Long, and N. Sigona (eds.), The Oxford Handbook of Refugee and Forced Migration Studies (Oxford: Oxford University Press, 2014), pp. 395-408 (398).

${ }^{9}$ J. G. Molz and S. Gibson, 'Introduction: Mobilizing and Mooring Hospitality', p. 15. 
humanity and benevolence. Furthermore, this way of constructing hospitality acknowledges how loaded and complex the concept "home" becomes when it is detached from ideas related to permanence and kinship. Nevertheless, it must be acknowledged that this way of understanding the concept is not popular. The Biblical narratives selected in this paper and the way the term is used in modern literature and popular culture align more closely with the perspective of hospitality which homogenizes and makes migrants into "Others" than with the Motz and Gibson's description.

\section{Hospitality and Migration in Judges 19}

Although in Hebrew there is no word for hospitality, ${ }^{10}$ the concept, perhaps most simply understood as receiving a guest, is certainly discernible within the Hebrew Bible. ${ }^{11}$ Judges 19 describes the migration of a Levite migrant (גר), temporarily based at the side of Mount

\footnotetext{
${ }^{10}$ Although the Greek term "love of strangers" $\varphi \imath_{\imath} \xi_{\xi} \varepsilon v i ́ \alpha$ and the term $\xi \varepsilon v i \zeta \omega$ which occurs in the LXX and NT must be acknowledged (Sir. 29:25; Rom. 12:13; Heb. 13:2). Of course, the problem with this definition of hospitality, indeed a problem inherent in the concept, is that it dichotomizes between groups understood as familiar and those interpreted as "strangers" or "foreigners". Through introducing the label stranger and foreigner, the focal point of interaction is of difference, often ethnic difference. Perhaps, therefore, a better way of thinking about hospitality is as Lipton argues 'as a motion directed inwards, drawing the beneficiary towards the giver.' D. Lipton, 'Kindness to Strangers: Biblical Hospitality and the Politics of Intervention' in M. J. M. Coomber, (ed.), Bible and Justice: Ancient Texts, Modern Challenges (London and Oakville: Equinox, 2011), pp. 195-211 [208].

${ }^{11}$ A range of literature within Biblical scholarship exists concerning the topic, some helpful recent contributions include F. M. Yamanda, Configurations of Rape in the Hebrew Bible: A Literary Analysis of Three Rape Narratives (New York and Oxford: Peter Lang, 2008), pp.72-85; S. Morschauser, “'Hospitality”, Hostiles and Hostages: On the Legal Background to Genesis 19:1-9’ JSOT 27/4 (2003), pp. 461-485; V. H. Matthews 'Hospitality and Hostility in Genesis 19 and Judges 19’ BTB 22/1 (1992), pp. 3-11.
} 
Ephraim, ${ }^{12}$ to collect $^{13}$ his secondary wife, or 'concubine' from her father's house. The concubine's father makes numerous attempts to retain the Levite, through the guise of "hospitality". The familiar generosity of three days' provision of hospitality following a journey is extended to a five day sojourn. The Levite is trapped by his host's exasperating "kindness" with reformulations of the entreaty to 'be in good spirits' on four occasions: לבך (Judg. 19:9). ${ }^{14}$ This is a stay which 'boarders on the excessive', leading Younger to wonder whether the Levite may have ended up being trapped indefinitely by such endless "hospitality" "had he chosen to remain in Bethlehem'. ${ }^{15}$ Through taking on the status of a migrant, the Levite finds himself in a position of reduced power and agency. He loses rights and instead gains generosity. As a

\footnotetext{
${ }^{12}$ One of the early manuscripts of the LXX (Codex Alexandrinus) simply has 'the man', a reading which is consistent with the scarcity of reference to the character's role as a 'Levite'. After 19:3, the character is called either 'the man' (Judg. 19:6, 7, 9, 10, 22-25, 28) or 'her husband' (Judg. 19:3; 20:4).

13 לדבר על לבה להשיבה, 'to speak tenderly to her and bring her back'. Following the qetib reading which, unlike
} the qere, has the feminine suffix on the hiphil infinitive שוב. Many of the LXX manuscripts have a double reading which incorporates both pronouns in order to deal with the confusion between the qere and ketib. As

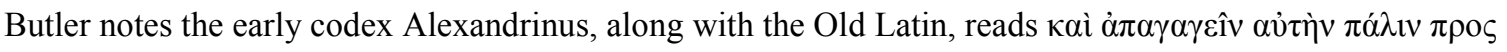

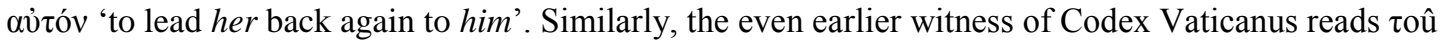

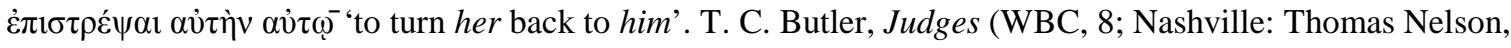
2009), p. 407. However, as BHQ notes, it is difficult to establish whether this sentence is a cumulative stylistic plus of Old Greek versions or whether it reflects a different Hebrew Vorlage. Concerning 'speak upon the heart' דבר + על לב, refer to note 48 .

${ }^{14}$ Echoed ironically later: מיטיבים את לבם (Judg. 19:22).

${ }^{15}$ K. L. Younger, Judges/Ruth (NIVAC; Grand Rapids, MI: Zondervan, 2002), 353. Lasine argues that there is an ominous absurdity about this topsy-turvy 'inverted' world where actions are 'often ludicrous' S. Lasine, 'Guest and Host in Judges 19: Lot's Hospitality in an Inverted World,' JSOT 29 (1984), pp. 37-59, (37). Refer also to V. H. Matthews, 'Hospitality and Hostility in Judges 4,' BTB 21 (1991), pp. 13-21. 
"guest", he must adhere to the inconvenient charity of his host who polices when the front door is open or closed.

The party leave the overbearing host's house suddenly, ${ }^{16}$ having eaten in the evening, and it is twilight ${ }^{17}$ by the time they enter into Jebus (Judg. 19:10-11). ${ }^{18}$ The Levite must now decide where best to sojourn to keep himself and his wife safe. The decision is a gamble; the company are very vulnerable and require shelter. Ironically, the Levite refuses to lodge in Jebus, instead, preferring the semi-security of the Benjaminite region, Gibeah (Judg. 19:1114). However, without any offers of shelter they are neglected and left sitting in the open (רחוב), desperate and unprotected from the elements. Sadly, this is the polar opposite of the domineering "hospitality" which we noticed at the beginning of the narrative; at this point the migrant family seem more aligned with the concept of the uninvited guests who simply just turn up in the hope of receiving asylum. Initially, not one offer of shelter emerges from the Benjamintes. One wonders why, despite the travellers having assets, they are ignored by the Benjamintes? It is striking that it is left to an elderly man who is also 'of Mount Ephraim,' but currently sojourning in Gibeah, to help. Shelter is provided but not by the supposed "host" society, rather from somebody who is already on the fringes both in terms of age and ethnicity.

\footnotetext{
${ }^{16}$ As represented by the swift succession of verbs describing the action of leaving 'and he rose up and he went and he came...' ויקם וילך ויבא (Judg. 19:10).

${ }^{17}$ As has been noted, there is a progression from full light to dark in vv. 8-14. This enhances the sense of anxiety and danger created by the narrative since darkness is considered perilous. Refer to W. W. Fields, 'The Motif “Night as Danger” Associated with Three Biblical Destruction Narratives,' M. Fishbone, (ed.) Sha'arei Talmon (Eisenbrauns:Winona Lake, 1992), pp. 17-32.

${ }^{18}$ Indeed, the LXX (Codex Vaticanus), emphasizes this twilight aspect of the narrative, stating 'Behold, the day has weakened into the evening (
} 
The amount of pressure on the Levite and the sheer vulnerability of the party begin to emerge more clearly in the conversation between the elderly Ephraimite and the migrating Levite. The Levite presents himself as pious figure claiming, perhaps in a fraught effort to receive shelter and protection, to be on his way to the temple (Judg. 19:18), rather than taking his secondary wife to return home with him as signalled earlier (Judg. 19:3). ${ }^{19}$ His emphasis on the plentiful provisions that he bears ${ }^{20}$ betrays his utter desperation but also his surprise at not being offered asylum. Under the strain of potentially being left out, the migrant Levite now uses every bargaining resource he has, including his woman, to find security.

The semi-security gained through finding a fellow Ephraimite in an unfamiliar city is soon shattered by the victimization of the non-Benjaminite migrant party as the "men of the

\footnotetext{
${ }^{19}$ It should be noted that there is some confusion in the versions concerning the phrase (and I am

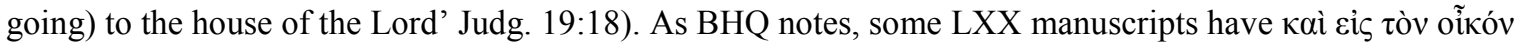
Hov 'and into my house'. The editors of BHS suggest the reading ואת ביתי 'and (to) my house' in light of v. 29 which has the third masculine suffix on house.
}

BHQ notes that in Judg. 19:29 the goal of the Levite's journey is his own house and that is not the normal introduction for the end of a journey. Indeed, הלך + את does not mean "go to" but "to travel, to traverse" or "to frequent", raising the possibility of reading the verse thus 'I frequent the Lord's house'. Therefore, although MT may be the cause of confusion in light of the contradicting manuscript evidence it should probably stand, but with the proviso that we understand the full nuances of הלך + את.

Note also the use of the first person pronouns in the Levite's speech, perhaps betraying a calculated move to deflect attention away from the woman, perhaps exasperated anxiety.

We אנחנו are crossing over from Bethlehem-Judah toward the side of mount Ephraim; from thence am I

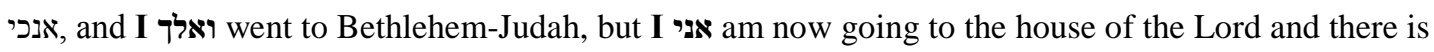
no man receiving me אותי to the house (Judg. 19:18).

${ }^{20}$ This emphasis is particularly marked through the Hebrew syntax which idiomatically repeats the particle גם: וגם תבן גם מספוא יש לחמורינו וגם לחם ויין יש לי

But there is both straw and fodder for our asses; and both bread and wine for me (Judg. 19:19). 
city' encircled the house, beating violently ${ }^{21}$ at the door requesting to homosexually rape $\mathrm{e}^{22}$ the stranger. Given the fact that the party are Ephraimites whose needs were previously ignored one wonders whether this isn't a racist attack on a vulnerable migrant; a suggestion consistent with hospitality metaphors where migrants are the powerless, dispossessed, anonymised, 'Other'. Indeed, all the information we are given about characters in the narrative is through ethnic epithets and statuses thus causing individuals to merge into groups. As Hudson argues 'every actor or victim is known by familial, tribal or national epithets - not as individuals with personal identity. ${ }^{23}$

The hospitality of the elderly Ephraimite's home is now cast against the broader concerns of the host city, a population who are happy to leave migrants out in the open and who seem to interpret their vulnerability as an opportunity for abuse. In theory, the hospitality offered by the Ephraimite puts him in a position of power since he can police the conditions surrounding his own door and within his home. The temporary "home" provided for the Levite and his concubine should, in theory, be closed off enough to offer shelter and open enough to allow guests to leave (unlike the restraining "hospitality" offered by the concubine's father earlier in the narrative). Nevertheless, this narrative mingles the concepts of hospitality, ethnicity, and migration. As such, the Ephraimite's power is restricted since he is an Ephraimite, not a Benjaminte, thus not in his home territory. Thus, he is not at home in Gibeah, he merely lives there. The ambivalent status of the elderly man is put into high drama with the request of the host city's inhabitants, whereupon he emphasizes his own role, also as host, stating:

Don't, אל אל אל my brothers, don't so wickedly. This man is my guest, don't

\footnotetext{
${ }^{21}$ Note the hithpael plural participle $\sqrt{ }$ דפק (literally 'beating themselves violently against the door').

${ }^{22}$ The request is a violation of the proscriptions against rape, sexual activity outside of marriage, and homosexuality (Exod. 22:15-16; Deut. 21:10-14; 22:25-27, 28-29; Lev. 18:22, 20:13).

${ }^{23}$ D. M. Hudson, 'Living in a Land of Epithets: Anonymity in Judges 19-21,' JSOT 62, (1994), pp. 49-66 (62).
} 
do this vile thing (Judg. 19:23).

It is asserted that the man is 'a guest in my house' and three times the Ephriamite says no, pleading that the infernal fellows (בני בליעל) suggestion is not only 'evil' רעל, it is also 'an outrage נבלה (Judg. 19:23). However, the danger the Levite migrant is in heightens as they fail to listen and we are told he grabs his wife and throws her outside. The woman never speaks and at this point she is portrayed as having no agency. Indeed, in this case she clearly has no choice. Through choosing to migrate, the Levite has put her and himself in a vulnerable position. However we shouldn't emphasise her victimisation at the expense of recognizing her agency at the beginning of the narrative where she was either 'angry' with her husband or she had 'prostituted herself'. ${ }^{25}$ Given this evidence, it would not be inconsistent to assume that she was forced to migrate by her husband having escaped him once. Nevertheless under the pressure of abnormal circumstances and migration, the Levite finds himself in a position where he must make an impossible choice. Either he will be raped and murdered or his secondary wife will. We are not given the reasons for his choice. Perhaps his primary wife needs him? Perhaps he has children in his home country? Perhaps he is so frightened that he acts in the heat of the moment and will forever regret his decision? We will never know. But what the narrative does put into stark perspective is the genuine

\footnotetext{
${ }^{24}$ The term נבלה is repeated in the next verse as the plea continues with a stronger prohibition לא, 'you shall not do this outrage'. The term נבלה is 'a serious disorderly and unruly action, resulting in the break-up of an existing relationship whether between tribes, within the family, in a business arrangement, in marriage or with God'. A. Phililps, 'Nebalah - A Term for Serious Disorderly and Unruly Conduct,' VT 25 1975, pp. 237-242 (241).

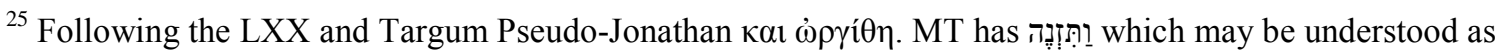
coming from זנה denoting illicit intercourse. Comparisons with Rahab in Joshua 2 may also be drawn. Refer to Y. Peleg, 'Was Lot a Good Host? Was Lot Saved from Sodom as a Reward for His Hospitality?' in D. Lipton (ed.) Universalism and Particularism at Sodom and Gomorrah: Essays in Memory of Ron Pirson (SBL AIL; Williston, US: SBL Press, 2012), pp. 129- 156 (136-139).
} 
vulnerabilities faced by migrants and the complex dynamics the metaphor of hospitality creates. In this story, members of the host city, Gibeah, do not feel obligations as host; doors are firmly closed.

\section{Hospitality and Migration in Genesis 19}

The metaphor of hospitality, both private and societal, is equally as pronounced in Genesis 19 as it is in Judges 19. Indeed, Lipton argues that ' $[\mathrm{t}]$ he entire episode can be read as a meditation on hospitality. ${ }^{26}$ From the narrative's opening we are informed that two strangers 'angels' have journeyed to Sodom. Lot enthusiastically offers to host them, but in an ironic contrast with Judges 19 , they refuse stating that they prefer to 'spend the night in the open' רחוב (פen. 19:2). ${ }^{27}$ Lot, like the concubine's father, pressed (פצר) then to stay with him as a guest (Gen. 19:3; Judg. 19:7). However, unlike Judges 19, the Sodom narrative cuts straight to the most shocking scene. As with Judges 19, 'men of the city' encircle (סבב) the house of the host and demand to rape, homosexually, the strangers who have just arrived. ${ }^{28}$ Lot,

\footnotetext{
${ }^{26}$ D. Lipton, 'Kindness to Strangers', p. 207.

${ }^{27}$ The many similarities between Judges 19 and Genesis 19 have long since been observed (Bib. Ant.45:2).

${ }^{28}$ It is striking that in Judges 19 'men of the city' is followed by 'infernal fellows' (בני בליעל), whereas in Genesis 19, it is followed by 'men of Sodom', perhaps tightening the connection between the place "Sodom" and the behaviour of infernal fellows. As Von Rad states 'Perhaps an ancient narrative ... about a frightful violation of the law of hospitality was connected only secondarily with Sodom as the seat of all sin' G. von Rad, Genesis: A Commentary (London: SCM Press, 1961), 213.

Also interesting is the emphasis placed on the fact that everyone has come out, achieved through the threefold description of 'both young and old, all the people, to the last man מקצה'. The syntax is a little unclear since it is not clear whether קצה should be understood spatially (it is usually an expression for 'the ends of the earth), but the emphasis on 'all the people' coming out is surely intended.
} 
attempts to protect his guests in a similar way to that of the old Ephraimite offering his own virgin daughter (or in Lot's case daughters ${ }^{29}$ ) and stating 'I beg you, don't אל my brothers, do not act so wickedly אל do do nothing these men for they have come under the shelter of my roof' (Gen. 19:8; cf. Judg. 19:23). Just as the Ephraimite had repeated said no and condemned the request as 'wicked' so too does Lot. However, Lot's defence is weaker than the Ephraimite's; indeed, he even emphasizes the commonality between himself and the Sodomites calling them 'brothers'. Von Rad suggests this address 'must not be censured as "too mild" since,

It is not the expression of a particularly friendly attitude but rather indicated a situation of legal equality, only on the basis of which Lot can deal with the men of Sodom at all. But he expected too much. He is told that he is a stranger and his right to act as arbitrator is thus in dispute. ${ }^{30}$

Von Rad's suggestion is particularly persuasive in light of the description of Lot as sojourning (גור) in the land, similarly to the Ephraimite (Gen. 19:9; Judg. 19:16). As the men state, 'this fellow came here as a single immigrant, and now he would play the supreme judge! $!^{31}$ Now we will deal worse with you than with them' (Gen. 19:9). Lot and the Sodomites are not equals: Lot is a migrant and therefore a "guest". Rosello's argument is Finally, it is worth noticing that in both requests for homosexual rape the host is instructed to cast out their guest or guests (using hiphil imperative יצאר) accompanied by the euphemism for intercourse to 'know' ידע (cf. Gen 4:1).

${ }^{29}$ Commentators often understand the offer of virgin daughters as a mark of 'hospitality' For example, Skinner suggested 'Lot's readiness to sacrifice the honour of his daughters ... shows him as a courageous champion of the obligations of hospitality in a situation of extreme embarrassment'. J. Skinner, A Critical and Exegetical Commentary on Genesis (ICC; Edinburgh: Clark, 1910), p. 307. The line between sexual exploitation and hospitality is dangerous burred in Skinner's description of hospitality here which links valour and heroism with rape. However, we must acknowledge the dated nature of the publication.

\footnotetext{
${ }^{30}$ von Rad, Genesis: A Commentary, p. 213.

${ }^{31}$ Note the Hebrew infinitive absolute וישפט שפוט.
} 
relevant here; the concept of hospitality, when applied to migration, blurs distinctions between rights and generosity and prevents migrants from fully feeling at home in the host society. ${ }^{32}$ As such he is an outsider who is under a debt of hospitality; he does not have an equal footing with the Sodomites and he is never truly going to be at home in Sodom, despite residing there, owing to his status as a recent migrant and therefore Other. As Wenham states 'there are no righteous in Sodom except for Lot, who is only an immigrant'. ${ }^{33}$ This observation makes the sad juxtaposition between Lot's individual and generous hospitality and the host country's hospitality (or, more accurately, aversion to migrants) all the more tragic. At the beginning of the conversation we are told that Lot goes out to the men and shuts the door after him (Gen. 19:6). These are the actions of a good host who endangers himself on behalf of his guests. As Wenham states 'by shutting the door, he cut off his own escape and hoped to protect those inside' ${ }^{34}$ Similarly, Peleg argues that 'the door symbolizes the wall separating not only the men of the city from Lot's guests but the moral distance between the men of Sodom and Lot himself. ${ }^{35}$ However, the observation that when the metaphor of hospitality is applied to migration it is the host country which 'polices the conditions by which the front door remains open or closed' is apt here. ${ }^{36}$ In Sodom, Lot's authority as individual "host" is undermined by his powerless position as a migrant "guest".

\footnotetext{
${ }^{32}$ Rosello, Postcolonial Hospitality.

${ }^{33}$ G. J. Wenham, Genesis 16-50 (WBC, 2; Waco, TX: Word Books), 55.

${ }^{34}$ Wenham, Genesis 16-50, p. 55.

${ }^{35}$ Peleg, 'Was Lot a Good Host?, p. 134. The text focuses repeatedly on entry and exit points such as gates and doors (Gen. 19:1, 2 [x2], 9, 10, 11 [x2]). This, as Lipton argues, 'emphasizes the centrality of notions of space in this narrative by highlighting the guests' movement from one side of the doorway to the other - who is inside and who is outside.' D. Lipton, 'Kindness to Strangers', p. 207; at this point Lipton cites B. Doyle “"Knock, Knock, Knockin' on Sodom's Door”: The function of xtptld in Genesis 18-19' JSOT 28, pp. 431-448.

${ }^{36}$ Molz and Gibson, 'Introduction, p. 12.
} 
Ironically, the verb פצר 'to press' now re-emerges in the Sodomites press Lot and attempt to break the door down in a similar way that the Benjaminites had hurled themselves at the Ephraimite's door (Gen. 19:9; Judg. 19:22). At this point, the comparisons with the narrative in Judges 19 cease. The Sodomites are struck with blindness, yet they nevertheless exhaust themselves in an effort to find the door. Given the horror of the concubine's rape and murder as a comparison the anti-climactic resolution of the narrative here is as comical as is it unrealistic. Nevertheless, the status and vulnerability of Lot and his family as migrants continues through the narrative. They cannot now stay in Sodom. Lot is told to 'flee for your life' and the party must not look back (Gen. 19:17). The urgent need to journey immediately is emphasized by the repetition of the term 'escape' מלט. This imperative occurs twice in swift succession during the instructions of the angels as well as a third time, also in the imperative, after Lot ponders his escape plans (Gen. 19:17[x2], 19, 20, 22). The relative stability which he had enjoyed as a migrant in Sodom is met with a sudden and unexpected need to journey again after an equally unexpected, vicious attack. ${ }^{37}$ Lot is now faced with a gamble; where to go? He decides to flee to the insignificant place Zoar. ${ }^{38}$ Like the narrative in Judges 19, this story illustrates emphatically the challenging choices and genuine vulnerabilities of migrants as a consequence of the metaphor of hospitality. Despite residing in Sodom, Lot can never really be at "home" there because in the eyes of the population at Sodom he is, as a migrant, a guest. Thus, paradoxically, despite being embedded in the city to

\footnotetext{
${ }^{37}$ The text highlights the unforeseen need to leave showing Lot (and his entire party if the Greek, which

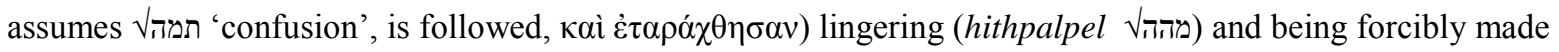
to leave (Gen. 19:16).

${ }^{38}$ Von Rad notes that 'it is probable that the section vs. 17-22 did not yet belong to an earlier version of the narrative.' von Rad Genesis, p. 215. Similarly, Driver suggested that this part of the narrative was an etiology 'to explain the origin of the name Zo 'ar'. Refer to S. R. Driver, The Book of Genesis (WC; London: Methuen, 1926), p. 200.
} 
the extent that he can act as a host, he can never really have the same status as other residents. His efforts at integration and hospitality are undercut by his position as a recent migrant, and therefore a "guest" of the population. He is a cheap target and when abuse comes knocking at his door - a door which he as host polices until his status as a migrant and guest takes this power away from him - he and his family have are forced to migrate and begin again somewhere else. His wife does not make the journey.

\section{Hospitality and Migration in Genesis 34}

This narrative launches straight into dramatic action:

Now Dinah the daughter of Leah, whom she had borne to Jacob, went out to visit the women of the region. ${ }^{39}$ When Shechem son of Hamor the Hivite, prince of the region, saw her, he seized her and lay with her by force.

Through the epithets the introduction makes it immediately obvious that there are two main groups involved in this encounter; those 'of the land' (the 'Hivites'), and those who have migrated to the land, (Jacob's family). Tensions are raised as a prince of the region, thus a native who is in a position of power and wealth, rapes ${ }^{40}$ a migrant woman. When conceived

\footnotetext{
${ }^{39}$ Literally 'to see the daughters of the land' לראות בבנותהארץ. Some confusion among the versions has been created by the qal infinitive ראה. The Samaritan Pentateuch has the niphal, and likewise Targum Neofiti has ithpaal (thus both passive and reflexive). Perhaps this emphasizes the reciprocal, peaceful arrangement with the women of the land. This would point to Dinah's previous acquaintance with the women and perhaps suggest that the Jacob group have been there long enough for Dinah to have become conversant with the "host" society. ויקח אתה וישכב אתה ויענה 'And he took her, and he laid her, and he raped her' perhaps expressing a single idea, similar to the way a hendiadys functions, or perhaps underlining the pace of the action. A very similar construction can be found in 2 Samuel 13:14. There are many parallels between Dinah's rape and that of Tamar in 2 Samuel 13. For a full discussion of the parallels refer to K. E. Southwood Marriage by Capture in Judges 21: An Anthropological Approach (Cambridge: CUP, forthcoming 2017), chapter 3. There is some discussion about whether the piel $\sqrt{ }$
} 
of in terms of hospitality, this rape highlights the vulnerability and victimization of Dinah. Rather than being a woman, just like any other, she is "guest" among the Hivites and can be treated differently. However, as noted, this metaphor is particularly erosive for migrant women since it fails to acknowledge their agency and power. Merely reducing Dinah to a dumb victim fails to take into account her confidence and her pre-existing friendships with the women of the land whom she 'goes forth' to see. ${ }^{41}$

In going forth, Dinah is displaying her confidence, mobility, and her level of assimilation. The land where she lives as a migrant seems to be the kind of "home" that instils 'the guest with a feeling of hope and a sense of being 'propelled' forward ... [a] hospitality [which] provides not only a place to be safely still, but also the hope of moving' ${ }^{42}$ Evidence for this perspective might be extrapolated through the emphasis on themes of

ענה points to rape, or whether it is simply "humiliation", in alignment with the LXX $\tau \alpha \pi \varepsilon$ עó $\omega$ 'to be humbled'. Refer to E. Van Wolde, 'Does 'innâ Denote Rape? A Semantic Analysis of a Controversial Word,' Vetus Testamentum 52/4 (2002), pp. 528-544. When used of sexual intercourse, the piel form of the verb ענה occurs twelve times in the Hebrew Bible (Gen. 34:2; Deut. 21:10-13, 14; 22:24, 29; Judg. 19:24; 20:5; 2 Sam. 13:12, 14, 22; Lam. 5:11; Ezek. 22:10-11). However, it is never used to refer to intercourse which is straightforwardly legally and social authorized or consenting. In this instance, the outrage produced seems to align with a case of rape, as does the question 'Should our sister be treated like a prostitute זנה?' Therefore the LXX translation 'humble' may be replicating the euphemistic style of the Hebrew at this point.

${ }^{41}$ Refer to note 39. Wenham suggests that Dinah's action in 'going forth' יצא may insinuate sexual impropriety: a prostitute 'goes out' to meet her client (Prov. 7:15). Refer to Wenham, Genesis 16-50, p. 310. This is unconvincing, as Blyth has illustrated, since the verb יצא can also refer to women going out to celebrate or worship at festivals (Exod. 15:20; Judg. 21:21; 1 Sam. 18:6; Cant. 3:11). Refer to C. Blyth, The Narratives of Rape in Genesis 34: Interpreting Dinah's Silence (Oxford: Oxford University Press, 2010), 170-171. The verb יצא is also used to describe the movement of Ruth and Naomi both in migration (Ruth 1:7,8) and in Judah where Ruth, a migrant who arrived with a return migrant (Naomi) goes out to meet the native women (Ruth 2:22).

${ }^{42}$ Molz and Gibson, 'Introduction', p. 15. 
assimilation and intermarriage which run through the narratives. This can be seen through the style of Hamor's request to Jacob's sons, a request which shows the commitment of the Hivites to the migrant group and their hope of re-establishing mutually peaceful co-existence, 'make marriages with us; give your daughters to us, and take our daughters for yourselves' (Gen. 34:9). ${ }^{43}$ This willingness of the Hivites to assimilate is emphasized in the following verses where the offer is made 'you shall live with us; and the land shall be open to you; live and trade in it, and get property in it' (Gen. 34:10). Furthermore, the invitation to the migrant community to co-exist peacefully in the land is emphasized through a third repetition in the narrative between Hamor and Shechem and the 'men of their city':

These people are friendly with us; let them live in the land and trade in it, for the land is large enough for them; let us take their daughters in marriage, and let us give them our daughters. Only on this condition ... that every male among us be circumcised as they are circumcised (Gen. 34:21-22). ${ }^{44}$

\footnotetext{
${ }^{43}$ Ironically, this mirrors exactly the command against intermarriage in Deuteronomy:

Do not intermarry with them, giving your daughters to their sons or taking their daughters for your sons (Deut. 7:3).
}

The insincere 'acceptance' of the Hivites' offer upon the lips of Jacob's sons repeats, perhaps sarcastically, this language:

Then we will give our daughters to you, and we will take your daughters for ourselves, and we will live among you and become one people עם אחד (Gen. 34:16).

${ }^{44}$ The language in Genesis 34:21 is formulaic, mirroring Deuteronomy 7:3. Unlike Deuteronomy 7:3 which emphasises lack of permission for interethnic marriages, this language refers to permission for interethnic marriage. However, what is interesting in this text, unlike Deuteronomy $7: 3$, is the lack of balance: only daughters are referred to. Perhaps this is a result of the context, where a daughter's potential marriage arrangements are the issue at stake. At this point in the narrative, there is an uncomfortable dynamic wherein hospitality and reconciliation revolve around sexual relationships. Refer to the work of T. Gur-Klein Sexual Hospitality in the Hebrew Bible: Patronymic, Metronymic, Legitimate, and Illegitimate Relations (Gender, Theology, and Spirituality. Sheffield and Oakville, CT: Equinox, 2013), pp. 6-58. 
Not only are the Hivites completely open to assimilation, they are also willing to take into account and embrace the customs and beliefs of the migrant group. In contrast to the Benjaminites of Judges 19 or the Sodomites of Genesis 19, the Hivites as a group demonstrate a more positive type of hospitality which welcomes strangers and draws them into the group. Furthermore, the Hivite "host" group itself are willing to be the ones who assimilate to the customs of the "guest," demonstrating their commitment to genuine assimilation.

However, it is inescapable that in all three narratives sexual misconduct, whether threatened or realised, against a migrant is a recurring motif. In all three narratives, this is condemned. It is רעע whickedness' when suggested to Lot and an 'outrage' נבלה when Dinah's brothers hear of it (Gen. 34:7; cf. Judg. 19:23-24). ${ }^{45}$ What makes Genesis 34 unique in this respect is the commitment Shechem has to Dinah. ${ }^{46}$ It is reported that Shechem's being 'cleaves to' דבק Dinah, he 'loved her' אהב and he 'encouraged' her (Gen. 34:3). ${ }^{48}$ Moreover, Shechem is described as being delighted חפק with Dinah (Gen 34:19). Particularly suggestive is the fact that Shechem will pay any bride-price for Dinah (Gen 34:11-12). ${ }^{49}$ Shechem now displays uncompromising enthusiasm to intermarry with Dinah. Generosity abounds in an

\footnotetext{
${ }^{45}$ Refer to note 24.

${ }^{46}$ This is perhaps the biggest contrast between Genesis 34 and Tamar's rape (cf. 2 Sam. 13:15-17).

${ }^{47}$ The expression נפש + דבק usually describes a deep-seated affection and loyalty between partners (Gen. 2:24; cf. Josh 23:12; Ruth 1:14; 2 Sam. 20:2).

${ }^{48}$ The idiomatic expression, literally 'spoke upon the heart' דבר על לב can occur in contexts denoting encouragement (2 Sam. 19:8; 2 Chr. 30:22; 32:6) or comfort (Gen. 50:21; Ruth 2:13; Isa. 40:2). However, the idiom is ambiguous; it may also be linked to persuasion as in the case of the Levite's concubine whom he convinces to return home with him (Judg. 19:3).

${ }^{49}$ This exceeds the legal penalties prescribed by Deuteronomy concerning rape (Deut. 22:28-29). However, the monetary offer may also be the motivation behind the question 'should our sister be treated like a whore זנה?'(Gen. 34:31).
} 
attempt to be pardoned by the offended migrant group with Jacob and in the hope of reconciliation. Furthermore, Shechem rushes off 'to do the thing' (circumcision) when the price is set. With such a willing "host" society and such an exaggerated attempt to atone for misconduct, why do the Jacob group resist? Indeed, why is their "revenge" so exaggerated?

Perhaps part of the reason is the heightened awareness of ethnic difference created by migration which makes migrants into "guests", anonymizes, and creates distinctions between groups. Jacob's awareness of potential vulnerability as a "guest" in the land is clear in his reaction to his sons' revenge; his sons have damaged his reputation and the group are vulnerable to attack (Gen. 34:30). Similarly, the brothers' anger and distress at their sister's rape can only be exacerbated by the fact that her rapist is a member of the host society. As Blyth argues the emphasis on ethnicity in relation to Shechem's offence suggests that 'her brothers evaluated her rape less as a personal attack against her than as a deliberate and combative attack perpetuated by Shechem against their group. ${ }^{50}$ This is certainly the implication in the phrase 'because they [the city] had defiled her [Dinah]' (Gen. 34:27). Through the concept of hospitality, individuals are anonymised as parts of groups, and strict dichotomous divisions are drawn between self and Other as well as public and private. Indeed, the private world of sexual encounter is made public in these narratives combining themes of hospitality and migration.

\section{Conclusion}

The theme of hospitality pervades all three narratives. In Judg. 19 and Gen. 19 individual hospitality is cast against the metaphor of the migrant as the uninvited, vulnerable guest. In contrast in Gen. 34, the host society are keen to assimilate and genuine hospitality is offered. However, all three narratives the theme of sexual exploitation of migrants emerges. In Judg.

\footnotetext{
${ }^{50}$ Blyth, The Narratives of Rape, p. 128.
} 
19 and Gen. 19 it is vast groups from the host society whereas in Gen. 34 it is a prince. A further common theme is the link between sexual exploitation and the concretization of boundaries. Since the party in Judg. 19 who seek asylum are unfamiliar migrants, the Benjaminites understand this as an opportunity for abuse. Through this act of sexual exploitation a sharp division is drawn between Benjamin and Israel, a division concretized violently in the subsequent narrative (Judg. 20-21). Similarly, a stark division is drawn between Sodom and Lot's family in the narrative of Genesis 19. This is not only represented spatially, with the city itself being the boundary between the groups - which must not be traversed by so much as a backward glance - but also morally through Sodom's destruction by Yahweh and Yahweh's protection of Lot's family (Gen. 19:23-26). Perhaps the most pronounced, and most saddening, division between groups occurs in Genesis 34 where a powerful and wealthy member of the host society rapes a migrant woman. The violent concretization of boundaries in response is very clear through the emphasis on ethnic division between Israel and the Hivites.

In current times with so many on the move and seeking asylum the metaphor of hospitality seems to transcend language and cultural barriers. However, only by reimagining what hospitality should be is it possible to break away from the damaging consequences of the metaphor. Perhaps one way of doing so is to describe migrants as individual fellow humans with tremendous potential who are welcomed, indeed invited, to be at home with us. To rephrase,

These people are friendly with us; let them live in the land and trade in it, for the land is large enough for them (Gen. 34:21). 